Volume: 14 Issue: 1 Year: 2017

\title{
Reviewing the relation between the problem solving skills of school of health students and their social skill levels ${ }^{1}$
}

\author{
Gül Ergün ${ }^{2}$ \\ Buket Şimşek Arslan ${ }^{3}$
}

\begin{abstract}
This research aims at reviewing the relation between the problem solving skills of health high school students and their social skill levels. It was planned to be descriptive. The universe of the research was composed of nursing students in the health high school. The sample was determined to be the whole of the universe. A written permission was taken from the management of the health high school regarding the research. Problem Solving Inventory and Social Skill Inventory; the form towards socio-demographic data prepared by the researchers was used. SPSS-16 software programme were used to analyze the data. The participants were a total of 248 people, with $\% 76.2$ female. 66 of the students are from the $1^{\text {st }}$ grade, 67 from the $2^{\text {nd }}, 58$ from the $3^{\text {rd }}$ and 57 from the $4^{\text {th }}$ grade. When some substance use properties of the students were observed, $\% 11.3$ stated they smoke, $\% 9.3$ of the students stated that they drink alcohol. Statistically significant relations were determined between problem solving and sub-scales regarding social skills. A statistically significant relationship was identified between confidence in the problem solving skills and emotional expressivity. According to this, as the score average for confidence in problem solving skills increase, emotional expressivity decreases. That is, the nonverbal communication skills of the individual are decreasing. Consequently, as the problem solving skills of nursing students decrease, their social skill levels are decreasing as well.
\end{abstract}

Keywords: Social skills; problem solving; health professional; nursing; nursing student

\section{Introduction}

Human is a social being in constant communication. There may be problems emerging among people in the course of communication for a number of reasons (Çam \& Tümkaya, 2008). To be able to cope with these problems, social skills such as the ability to solve problems, to establish effective communication and to be tolerant are highly required (Akpinar, 2014). Problem-solving is an important precursor of social skills (Durualp, Arslan, Çayıroğlu, Özkan, \& Semerci, 2009). Becoming a successful problem solver requires being good at social skills in particular as well as possessing effective communicative skills (Çam, 1999).

As a concept that represents complicated, troublesome and undesired conditions, the term 'problem' stands for the circumstances experienced frequently during the processes of a lifetime.

\footnotetext{
1 This study was presented as a poster paper in Turkish Psychiatry Association 18th Annual Meeting and Clinical Education Symposium and the absract of this study was published in Turkish Journal of Psychiatry.

${ }^{2}$ Assistant Professor, Ph.D., Mehmet Akif Ersoy University, Faculty of Health Science, Department of Emergency Aid and Disaster Management, ergun@mehmetakif.edu.tr

3 Research Assistant, Akdeniz University, Faculty of Nursing, Department of Psychiatry Nursing, buketsmsek@gmail.com
} 
Ergün, G., \& Șimșek Arslan, B. (2017). Reviewing the relation between the problem solving skills of school of health students and their social skill levels. Journal of Human Sciences, 14(1), 902-913. doi:10.14687/jhs.v14i1.4384

Problem-solving, on the other hand, is the process of overcoming the challenges that are encountered in attaining a goal, which necessitates making use of the methods related to creativity and resolution as well as knowledge (Yalçı, Tetik, \& Açıkgöz, 2010). In other words, problemsolving is a series of cognitive, emotional/affective and behavioural processes aiming at adapting to intrinsic or extrinsic desires (Çağlayan, Taşğın, \& Yıldız, 2008).

Social skills, however, are certain behaviours to be exhibited by the individual so as to be able to fulfill the tasks expected by the society. Those incapable of displaying social skills have a hard time in establishing mutual and healthy relationships with other people, in addition to which they have trouble in emotional and behavioural fields, and they face with different problems in their academic and professional lives (Akpinar, 2014). Besides receiving, resolving and understanding the social information in interpersonal relationships, social skills comprise learnable behaviours that include exhibiting an appropriate reaction as well as both observable and unobservable cognitive and affective/emotional elements that are target-specific and that vary according to social context (Şahin, 2001).

Nursing care came to the fore in the 1960s when mental and abstract skills, such as determining the needs of an individual and finding out ways for proper solutions, were required. During this period, it was determined also by various nursing theorists that the major requirements of nurses in the clinical field were problem-solving and decision-making skills. In the 1960s, Abdellah focused on the problem-solving approach for a qualified nursing care. Within the same year, Orem emphasized the fact that nursing as an art had a mental direction, such as making a decision on what to do and planning the task to be performed. Levine (1960), however, ascertained that protective and therapeutical nursing care had to be based on a firm foundation of knowledge (Taşç1, 2005).

As for nurses, the problem-solving skill is based on the power of knowledge. A nurse receives this knowledge throughout the educational process (Çinar, Sözeri, Şahin, Cevahir, \& Say, 2010). The contribution of education and educational institutions to the development of the skills of solving the experienced problems is, indeed, great (Karabulut \& Pulur, 2011), since the objective of education is to develop the necessary skills of students for their adaptation to their personal and social environments as well as contributing to their academic and professional developments (Şahin, 2001).Within this context, education, throughout the educational stages individuals mandatorily go through, aims at providing effective problem-solving skills for individuals in the face of the problems they experience as well as teaching them how to behave under certain circumstances. Individuals can lead healthy, peaceful and happy lives to the extent that they are capable of solving the problems they confront throughout their lifetime. In this context, becoming accomplished and getting pleasure out of life on the part of the individuals depend on their ability to possess problem-solving skills in the most appropriate fashion (Saracaloğlu, Serin, \& Bozkurt, 2001).

Problem-solving and social skills are the skills that promote one another. In other words, it is not right to expect a good social skill ability from an individual who has no problem-solving skill, or a good problem-solving skill cannot be expected from those who have no social skill capacity. It is best to consider these two skills, not as separately whole but as the pieces that constitute the whole. Considering the individuals that utilize these skills well, it is seen that they come much closer to realizing themselves, not by associating these skills independent of each other but by associating them with one another (Akpinar, 2014).

Nurses aim to bring solutions to problems by benefiting from the scientific method. The scientific problem-solving method shows parallelism with the problem-solving process in nursing care (Taşç1, 2005). Nurses confront several difficulties while providing care for their patients and feel obliged to 

students and their social skill levels. Journal of Human Sciences, 14(1), 902-913. doi:10.14687/jhs.v14i1.4384

make major decisions regarding their patients. For this reason, having nurses gain problem-solving skills during nursery education is necessary for performing this career in a professional way (Kim \& Choi, 2014). When the problems experienced in performing nursing profession in our country are taken into consideration, it is clear that there is the need to graduate the individuals with advanced problem-solving skills (Olgun, Öntürk, Karabacak, Arslan, \& Serbest, 2010).

Nursing is a career field in which too many problems are experienced, requiring an intensive communication with patients and their families (Mueller et al. 2002). Due to the fact that nurses have excessive work load and mission in which their authority and responsibilities are unclear, they face problems with both their own occupational groups and the other ones (Altuntass \& Harmanc1, 2010). In the resolution of these problems, it is necessary that individuals possess proficient social skills and a good level of problem-solving skills. It is thought that solving problems and establishing secure communications are closely associated with the nurse's problem-solving skill and social skill level. Examining the problem-solving and social skill levels of nursing students will help develop the course contents for identifying the existing negative situations in the early stage and for teaching proper ways of development.

\section{Purpose}

The main objective of this research is to examine the relationship between the problem-solving skills and social skill levels of health college students. The answers to the following questions were sought within the frame of this main objective:

1. At what level are the problem-solving skills of health college students?

2. At what level are the social skills of health college students?

3. Is there a relationship between the problem-solving aptitudes and social skill levels of health college students?

\section{Method and material}

\subsection{The place and time of the study}

The research was conducted on the students of the department of nursing care in a health college in March 2012.

\subsection{Population and sample selection}

The research population comprised the students attending the department of nursing care in a health college $(\mathrm{N}=330)$. Reaching the whole population was targeted as for the sampling process, and $75.1 \%(n=248)$ of the population was reached. As for the participation in the research, the principle of volunteerism was taken into account.

\subsection{Type of study}

This research is the descriptive type of a field study.

\subsection{The variables}

The dependent variable of this research is level of social skills and level of problem-solving skills and independent variable is gender and class 
Ergün, G., \& Șimșek Arslan, B. (2017). Reviewing the relation between the problem solving skills of school of health students and their social skill levels. Journal of Human Sciences, 14(1), 902-913. doi:10.14687/jhs.v14i1.4384

\subsection{Data collection}

Data collection was performed by the researchers through face-to-face interview method, during which the researchers prevented the sampling group from getting influenced by one another.

\subsubsection{Data collection method}

In the data collection process, 'Data Collection Form', 'Problem-Solving Inventory' and 'Social Skill Inventory' were used for the socio-demographic data formed by the researchers.

\subsubsection{Data collection tools}

Socio-Demographic Data Form: Within this form, the students were asked about their gender, marital status, what grade they attended, the high school they graduated from, their alcoholsmoking habits, the educational status of their parents, their occupations, the number of their siblings, the family structure they grew up in, the income status of their parents, the place they lived for a longer period of time, the place they are living at present and how they perceived themselves as individuals.

Problem-Solving Inventory (PSI): PSI was developed by Heppner and Peterson in 1982 (Şahin, Şahin and Heppner 1993). In this inventory, how the individual perceives him/herself in the problem-solving process and what $\mathrm{s} /$ he thinks of the problem-solving behaviour are evaluated. It consists of a total of 35 items, including three sub-inventories. The sub-inventories are related to confidence in the problem-solving ability, approach-avoidance and personal control. It is six-point likert scale. The lowest score to be obtained from the inventory is 32, whereas the highest score to be gained is 192. In the inventory, three questions are excluded from the scoring process. This inventory is performed on adolescents and adults. The fact that the total score obtained from the inventory proves to be high suggests that the individual perceives him/herself as unproficient in problem-solving, whereas the low total score suggests that the individual feels proficient in problem-solving. The Turkish validity and reliability study of the inventory was performed by Şahin et al. (1993). In the study conducted by Şahin et al., the alpha reliability coefficient for the whole inventory was found to be .88 , whereas, in our study, it proved to be .84 .

Social Skill Inventory (SSI): SSI was developed by Riggio in 1986 for the purpose of measuring the basic social skills, and it was revised in 1989 and took its final shape as of today. This is a type of self-report tool consisting of a total of 90 items and six sub-inventories. The sub-inventories involve emotional (affective) expressivity, emotional susceptibility, emotional control, social expressivity, social sensitivity and social control. The emotional expressivity sub-scale measures the non-verbal communicative skills of the individuals, particularly the skill of transmitting emotional messages. The emotional susceptibility sub-scale measures the skill of receiving and decoding the non-verbal messages of others. The emotional control sub-scale measures the individuals' skills in arranging and controlling the emotional or non-verbal reactions. The social expressivity sub-scale measures verbal expressivity as well as the skill of establishing a social communication with other individuals and taking part in the communication. The social sensitivity sub-scale, on the other hand, measures the skill of receiving and decoding the verbal messages of others. Finally, the social control sub-scale measures the skill of playing the social role and social self-assertiveness of the individual (Özdemir, 2007). Each of the sub-inventories consists of 15 items each. It is five-point likert scale. The lowest total score to be obtained from the inventory pertaining to the individual is 90, whereas the highest score to be gained is 450.The Turkish validity and reliability study of the inventory was performed by Yüksel (1998). In the study conducted by Yüksel, the alpha reliability coefficient for the whole inventory was found to be .85 , whereas, in our study, it proved to be .82 . 
Ergün, G., \& Șimșek Arslan, B. (2017). Reviewing the relation between the problem solving skills of school of health students and their social skill levels. Journal of Human Sciences, 14(1), 902-913. doi:10.14687/jhs.v14i1.4384

\subsection{Limitations of study}

This study is limited to the study-made only health high school students.

\subsection{The generalizability of the study}

The research can only be generalized to the students in the applied center.

\subsection{Research ethics}

For the research, a written approval was received from the Administration of School of Health, and the students were informed about the scales to be used, after which their verbal consents were received, as well.

\subsection{Evaluation of data}

The data were evaluated on the SSPS.16 program by using percentages, frequencies, mean/median, standard deviation and correlation analysis.

\section{Results}

The participants consist of 190 female and 58 male students, 3 of whom are married and 245 of whom are single. Their distribution according to the Grades (classes) they attend is as follows: $1^{\text {st }}$ Grade is $26.6 \%(\mathrm{n}=66) ; 2^{\text {nd }}$ Grade is $27 \%(\mathrm{n}=67) ; 3^{\text {rd }}$ Grade is $23.4 \%(\mathrm{n}=58)$, and $4^{\text {th }}$ Grade is $23 \%$ $(n=57)$. When the students were asked to evaluate themselves in a general sense, $48.8 \%$ of them regarded themselves as successful, $43.5 \%$ of them regarded themselves as partially successful, $4.8 \%$ of them considered themselves as quite successful, whereas $2.8 \%$ of them considered themselves as unsuccessful individuals.

Table 1: The Mean Scores of the Students that were obtained from the Sub-Dimensions of Problem-solving Inventory (PSI)

Problem-Solving Dimensions (the number $\mathrm{X} \pm \mathrm{SD}$ of acceptable/valid items: 32) score range score range

\begin{tabular}{lccc}
\hline Confidence in the Problem-Solving Ability & $31.12 \pm 6.754$ & $17-57$ & $11-66$ \\
\hline Approach - Avoidance & $53.20 \pm 7.430$ & $23-76$ & $16-96$ \\
\hline Personal Control & $19.31 \pm 4.938$ & $7-23$ & $5-30$ \\
\hline Total Problem-solving & $89.94 \pm 17.29$ & $47-152$ & $32-192$
\end{tabular}

While $77.8 \%$ of the sampling groupare not involved in any branch of art, $22.2 \%$ of them are engaged in these subjects. $68.1 \%$ of them are not involved in any sports branch, whereas $31.9 \%$ of them are involved in this field. The lowest score to be obtained from the scale is 32 , whereas the highest score could be 192, and the fact that the total score obtained from the scale proves to be high suggests that the individual perceives him/herself as insufficient/unproficient in problemsolving skills. The same evaluation also goes for the sub-scales. The total mean scores of the participants that were obtained from the problem-solving inventory were found to be 89.94. The mean score for Confidence in the Problem-Solving Ability proved to be 31.12, whereas the mean score for Approach - Avoidance was 53.20, and the mean score for Personal Control was found to be 19.31 . 
Ergün, G., \& Șimșek Arslan, B. (2017). Reviewing the relation between the problem solving skills of school of health students and their social skill levels. Journal of Human Sciences, 14(1), 902-913. doi:10.14687/jhs.v14i1.4384

Table 2: The Mean Scores of the Students that were obtained from the Sub-Dimensions of Social Skill Inventory (SSI)

\begin{tabular}{lccc}
$\begin{array}{l}\text { Social Skills Sub-Dimensions(the } \\
\text { number of valid items: 90) }\end{array}$ & $\mathbf{X} \pm \mathbf{S D}$ & score range & scoring \\
\hline Social Control & $52.02 \pm 9.06$ & $15-73$ & $15-75$ \\
\hline Social Sensitivity & $46.34 \pm 7.70$ & $29-69$ & $15-75$ \\
\hline Social Expressivity & $44.26 \pm 8.41$ & $21-71$ & $15-75$ \\
\hline Emotional Expressivity & $46.46 \pm 6.64$ & $21-71$ & $15-75$ \\
\hline Emotional Susceptibility & $48.41 \pm 8.40$ & $25-72$ & $15-75$ \\
\hline Emotional Control & $42.59 \pm 8.05$ & $17-70$ & $15-75$ \\
\hline Total Social Skill & $280.31 \pm 2.71$ & $208-362$ & $90-450$
\end{tabular}

The lowest total score to be obtained from the whole social skill inventory is 90 , whereas the highest score could be 450 . On the other hand, the lowest score to be obtained from the sub-scales is 15 , while the highest score could be 75 .

The total mean scores of the participants pertaining to the Social Skill Inventory were found to be 280.31. The mean sub-scale scores, however, were determined as follows: Emotional Expressivity proved to be 46.46, whereas Emotional Susceptibility was 48.41; Emotional Control was 42.59; Social Expressivity proved to be 44.26, while Social Sensitivity was 46.34, and Social Control was found as 52.02.

Table 3: The Analysis of the Relationship between Problem-solving and Social Skill Levels in terms of all Sub-Scales

EE

ES

EC SE SS

SC

\begin{tabular}{ccc}
$\begin{array}{c}\text { Confidence } \\
\text { in the }\end{array}$ & Approach & Personal \\
Problem- & - & \\
Solving & Avoidance & Control \\
Ability & & \\
\hline
\end{tabular}

\begin{tabular}{|c|c|c|c|c|c|c|c|c|c|c|}
\hline \multirow[t]{2}{*}{ EE } & $\mathrm{r}$ & 1,000 & & & & & & & & \\
\hline & $\mathrm{p}$ & 0,000 & & & & & & & & \\
\hline \multirow[t]{2}{*}{ ES } & $\mathrm{r}$ & $0,223^{* *}$ & 1,000 & & & & & & & \\
\hline & $p$ & 0,000 & 0,000 & & & & & & & \\
\hline \multirow[t]{2}{*}{ EC } & $\mathbf{r}$ & $-0,127^{*}$ & 0,109 & 1,000 & & & & & & \\
\hline & $\mathrm{p}$ & 0,046 & 0,086 & 0,000 & & & & & & \\
\hline \multirow[t]{2}{*}{ SE } & $\mathbf{r}$ & $0,419 * *$ & $0,580^{* *}$ & $0,204^{* *}$ & 1,000 & & & & & \\
\hline & $\mathrm{p}$ & 0,000 & 0,000 & 0,001 & 0,000 & & & & & \\
\hline \multirow[t]{2}{*}{ SS } & $\mathbf{r}$ & $-0,009$ & $0,320 * *$ & $-0,236^{* *}$ & 0,006 & 1,000 & & & & \\
\hline & $p$ & 0,884 & 0,000 & 0,000 & 0,927 & 0,000 & & & & \\
\hline \multirow[t]{2}{*}{ SC } & $\mathbf{r}$ & $0,333^{* *}$ & $0,277^{* *}$ & $0,140^{*}$ & $0,540^{* *}$ & $-0,295^{* *}$ & 1,000 & & & \\
\hline & $p$ & 0,000 & 0,000 & 0,027 & 0,000 & 0,000 & 0,000 & & & \\
\hline \multirow{2}{*}{$\begin{array}{l}\text { Confidence } \\
\text { in the } \\
\text { Problem- } \\
\text { Solving } \\
\text { Ability }\end{array}$} & $\mathbf{r}$ & $-0,188^{* *}$ & $-0,331^{* *}$ & $-0,095$ & $-0,394 * *$ & $-0,020$ & $-0,331^{* *}$ & 1,000 & & \\
\hline & $\mathrm{p}$ & 0,003 & 0,000 & 0,136 & 0,000 & 0,754 & 0,000 & 0,000 & & \\
\hline \multirow{2}{*}{$\begin{array}{l}\text { Approach } \\
- \\
\text { Avoidance }\end{array}$} & $\mathbf{r}$ & $-0,032$ & $-0,127^{*}$ & 0,013 & $-0,122$ & $-0,005$ & $-0,044$ & $0,493^{* *}$ & 1,000 & \\
\hline & $\mathrm{p}$ & 0,616 & 0,046 & 0,843 & 0,054 & 0,932 & 0,486 & 0,000 & 0,000 & \\
\hline \multirow{2}{*}{$\begin{array}{l}\text { Personal } \\
\text { Control }\end{array}$} & $\mathbf{r}$ & 0,031 & $0,142^{*}$ & 0,034 & $0,195^{* *}$ & $-0,176^{* *}$ & $0,342^{* *}$ & $-0,126^{*}$ & 0,110 & 1,000 \\
\hline & p & 0,623 & 0,025 & 0,594 & 0,002 & 0,005 & 0,000 & 0,047 & 0,083 & 0,000 \\
\hline
\end{tabular}

EE: Emotional Expressivity, ES: Emotional Susceptibility, EC: Emotional Control, SE: Social Expressivity, SS: Social Sensitivity, SC: Social Control

${ }^{*} \mathrm{p}<0.01$ and ${ }^{* *}$. Correlation is significant 
Ergün, G., \& Șimșek Arslan, B. (2017). Reviewing the relation between the problem solving skills of school of health students and their social skill levels. Journal of Human Sciences, 14(1), 902-913. doi:10.14687/jhs.v14i1.4384

Statistically significant relevances were found between the sub-scale scores pertaining to problemsolving and social skill. A statistically significant relationship in a negative direction was found between the score of Confidence in the Problem-Solving Ability and Emotional Expressivity score $(\mathrm{r}=-0.188 ; \mathrm{p}=0,003<0.05)$. Accordingly, as the confidence in problem-solving ability diminishes, so does Emotional Expressivity.

Table 4: The analysis of the Relationship between the Total Scores pertaining to Problem-solving and Social Skill Levels

Scales

Problem-solving

n $\quad \mathbf{r}$

$\mathrm{p}$

\section{Social Skill Level}

${ }^{*} \mathrm{p}<0.001$ and ${ }^{* *}$. Correlation is significant

A correlation in a negative direction was found between the total scores of problem-solving inventory and social skill level $(\mathrm{r}=-0,419 ; \mathrm{p}<0,000)$. As the problem-solving score goes up (as the problem-solving level goes down), the social skill score drops down.

\section{Discussion}

In this section were the problem-solving inventory and the social skill inventory scores of the participants and the relationship between these scores were interpreted.

\section{The Interpretation of the Findings regarding the Scores obtained by the Students from the Problem-solving Inventory (PSI)}

The Mean Total Scores of the participants pertaining to the Problem-solving Inventory were found to be 89.94 . The lowest score to be obtained from the scale is 32 , whereas the highest score could prove to be 192, and the fact that the total scores obtained from the scale prove to be high suggests that the individual perceives him/herself unproficient in problem-solving skills. On the basis of this, and as the result of our research, it can be stated that the mean total score (89.94) obtained from the scale by the students of nursing care is below the moderate level and that the problemsolving levels of the students are sufficient (Table 1). Similar results have been found in the studies conducted in our country with respect to the problem-solving skills of the students of the nursing department (Bayındır and Olgun 2014, Kanbay et al. 2013, Kara 2012, Şahiner et al. 2013, Olgun et al., 2010, Aştı et al. 2009, Tezel et al., 2009,Yıldırım et al. 2009, Akın et al. 2007).

There are also other studies in the international literature that demonstrate different results. Sook Kim and Hyun Choi (2014), in their research in which the relationship among critical thinking, the perception of professionalism and problem-solving skills of the students of the nursing department was examined, found that the problem-solving skills of the students had proved to be rather high. Yoo and Park (2014), on the other hand, in a similar study they conducted, also found that the problem-solving levels of the students of the nursing department were high. Yang (2010), however, found that the problem-solving skills of the students of the nursing department in South Korea had proved to be rather low.

In the studies conducted on the decision-making process, which is one of the problem-solving steps in nursing care, it was shown that the major sources of stress regarding the working environment of nurses were their incompetency in autonomy and in taking part in the decisions made for patients as well as the lack of appreciation towards their individual capabilities (Taşç1 
Ergün, G., \& Șimșek Arslan, B. (2017). Reviewing the relation between the problem solving skills of school of health students and their social skill levels. Journal of Human Sciences, 14(1), 902-913. doi:10.14687/jhs.v14i1.4384

2005). In our study, the personal control score (19.31) pertaining to the problem-solving inventory that indicates to the ability of individuals to maintain control under problematic conditions was found at an average level. One who thinks that the problem encountered is too challenging to be ever solved and that $\mathrm{s} / \mathrm{he}$ is not the controller of that situation will never attempt to figure out the problem at hand. Both the problem experienced by the individual and the evaluations of the individual pertaining to him/herself are the determinants in the problem-solving process (Eskin, 2009). In this respect, since the student with an average level of inner control focus will be able to be aware of his/her own contribution to the problem at a certain level, s/he will, therefore, take that amount of responsibility in order to solve the problem.

In the research conducted by Yildirm et al. in 2009, the personal control score (19.65) of the students of the nursing department of health college yielded the same results as those in our research. Tezel et al. (2009), in a study they conducted, as well as Sook Kim and Hyun Choi (2014), in their study conducted on nursing students, found that the mean personal control sub-scale score of the nursing students pertaining to the problem-solving inventory had proved to be rather low. In other words, the students' perceptions of their inner control in the problem-solving process were determined to be quite good.

The fact that the inner-control perceptions of the nursing students who had participated in these studies proved to be sufficient is quite promising for the future of nursing profession, since the fact that the control perceptions of the nurses establishing a peer-to-peer communication at most with the patients in health institutions are sufficient in coping with the problems they confront is of great importance in terms of figuring out the problems before they brew, increasing the satisfaction of patients and their families with respect to the health service provided for them as well as ensuring the job satisfaction the individual gets while in charge.

\section{The Interpretation of the Findings regarding the Score obtained by the Students from the Whole Social Skill Inventory (SSI)}

According to the result of the research, the highest mean scores of the nursing students pertaining to the social skill inventory are as follows: Social Control, Emotional Susceptibility, Emotional Expressivity, Social Sensitivity, Social Expressivity and Emotional Control, respectively. Considering that the highest score to be obtained from the whole inventory is 450 , the mean score $(280,31)$ obtained by the students from the grading/gradation scale can be accepted as quite a good one. In line with this, the social skill levels of the students of the department of nursing care can be said to be high in a general sense.

One of the elements of Daniel Goleman's definition of emotional intelligence, social skill is an important concept for almost all occupational groups. A person with a high social skill level is a challenger in getting in contact with people. This type of person can easily understand the thoughts and emotions of others, analyze them and may even direct their behaviors by easily posing an influence on them (Ünsar et al., 2009). The social skill levels of the students who will be the nurses of the future must be high in order for them to figure out the conflicting moments and abruptlydeveloping problems in their career which necessitates being in contact with patients 24/7.

The findings of the study conducted by S.enyuva et al. (2014), in which the social skill levels of the students of the department of nursing care were examined, proved to be similar to the findings of our research conducted on the social skill levels of the nursing students. There are also studies conducted in our country that yield similar results regarding the social skill levels of the nursing students (Durualp et al., 2009). The studies conducted for determining the social skill levels of the nursing students in our country are few in number. For this reason, the students attending different 
Ergün, G., \& Șimșek Arslan, B. (2017). Reviewing the relation between the problem solving skills of school of health students and their social skill levels. Journal of Human Sciences, 14(1), 902-913. doi:10.14687/jhs.v14i1.4384

fields of universities and the social skill levels of careerists will be taken into consideration in the discussion. Yalçin (2012) found that the social skill levels of the students of the department of preschool teaching were high. The social skill levels of the teacher candidates proved to be rather higher than those of the nursing candidates. The results of the study conducted by Avşar and Kuter (2007), in which the social skill levels of the students of the department of physical education and sports were examined, show parallelism with our research findings. The findings of the study by Avşar (2004), in which the social skill levels of the students of the department of physical education and sports were determined, yielded results similar to those in our research.

\section{The Interpretation of the Relationship between the Sub-Scale Scores of the Students pertaining to Social Skill Inventory (SSI) and Problem-solving Inventory (PSI)}

There is a negative correlation between the score of confidence in the problem-solving ability and emotional expressivity score. When the score of confidence in the problem-solving ability goes up, this suggests that the individual loses his/her confidence in the face of problems. In this case, the low level of emotional expressivity of the individual is an expected outcome. As one's confidence in his/her problem-solving ability diminishes, his/her ability to use non-verbal communicative skills and the rate of transmitting emotional messages decrease, as well. These two concepts can be easily affected by one another.

Blanchard Fields (2007) stated that the capability of emotional expressivity developed in time in humans, reaching the most efficient level during adulthood in particular; yet, it became inadequate in the old age, and thus, adults could become more successful and efficient in problem-solving in this respect. Also in our study, the confidence of the individuals in their problem-solving ability during their adolescence were found to be at good levels, in addition to which the emotional expressivity of the students who had great confidence in their problem-solving ability was also found to be at a good level.

The good level of emotional expressivity skills of nursing students suggest that they can use their non-verbal communicative aptitudes quite well, in addition to which their skills in transmitting emotional messages are quite good, as well. In this respect, the results regarding the future members of nursing career who will be in continuous contact with patients are quite positive.

There is a negative correlation between the score of confidence in the problem-solving ability and the emotional expressivity score. The scores of both are on a positively acceptable level. As the score of confidence in the problem-solving ability goes up, the emotional susceptibility score goes down. In other words, when the confidence in the problem-solving ability diminishes, the skill of receiving and interpreting others' thoughts and emotions and the ability to empathize with others diminishes, as well. Since it is important to collect information about the involved problem and to comprehend the cause of the problem in the problem-solving behaviour, empathy, at this stage, is the skill that will help one identify the problem in a correct manner (Genç \& Kalafat, 2010). An individual with a good emotional susceptibility level can easily perceive and understand the nonverbal clues of another. In order for nurses to be able to understand their patients better, they should attach importance to their patients' emotions and thoughts as well as empathizing with them. The result of our research is satisfying in terms of these criteria and is also promising in terms of the future of nursing career.

As the score of confidence in the problem-solving ability increases, the social control score decreases. In other words, as the confidence in the problem-solving ability decreases, the social control decreases, as well, which is a possible outcome. Social control is a field involving the individuals' skills in fulfilling their social roles (Yüksel, 1998). Individuals with advanced social 
Ergün, G., \& Șimșek Arslan, B. (2017). Reviewing the relation between the problem solving skills of school of health students and their social skill levels. Journal of Human Sciences, 14(1), 902-913. doi:10.14687/jhs.v14i1.4384

control are usually assertive people in their social relationships. They are effective in leading the way to communication in social relationships (Güçlü, 1996). Nurses confront several problems in their professional lives. When nursing students are proficient in their social roles, this suggests that they are also capable of coping with the problems they encounter in their own lives.

Luthar (1991) investigated the factors affecting the social skill levels of the students during their adolescence, and in his study, he stated that the frequency of coping with stress and confronting distressful life events on the part of an adolescent individual directly affected the individual's adaptation to his/her roles in social life. In this regard, the fact that both the confidence in the problem-solving ability and the social control level which are inter-related proved to be adequate in our research is quite a pleasing outcome.

A negative correlation was found between the emotional susceptibility score and the approachavoidance score which is another factor of the Problem-solving Inventory. In other words, as the approach-avoidance level decreases, the emotional susceptibility decreases, as well. Approach tendency is the tendency of struggling with problems. In contrast, avoidance tendency is the tendency of giving up on coping with problems, or being dependent on others in solving problems (Çam and Tümkaya, 2008). The approach-avoidance factor is the review made by the individual as regards the initial problem-solving efforts so that s/he may use it in the future (Şahin, Şahin, \& Heppner, 1993). The individuals who exhibit the behaviour of reviewing their efforts to solve problems are expected to be those who have good emotional susceptibility; since an individual who has a good perceptual level towards the other person and who is able to recognize and analyze the non-verbal communicative elements easily is expected to review the problem, when faced with one, without avoiding it. In this respect, our research result is quite pleasing for the sake of the individuals who participated in the research and for the future nursing career.

\section{The Interpretation of the Relationship between the Total Scale Scores of the Students pertaining to Social Skill Inventory (SSI) and Problem-solving Inventory (PSI)}

A correlation in a negative direction was determined between the mean scale scores. As the problem-solving score increases, the individual perceives him/herself as insufficient/unproficient. The rise in the social skill score represents the fact that the social skill level of the individual has increased, as well. Accordingly, while the problem-solving score increases, that is, as the individual's perception level in considering him/herself as insufficient increases when s/he confronts a problem, the decline in the social skill level is an expected outcome. The ability of an individual with a high social skill level to figure out the problems confronted during his/her lifetime by focusing on them is also an expected outcome. However, the incapability of an individual with a decreased social skill level in having difficulty in interpersonal relationships and in solving life's problems is, in the same way, a possible outcome.

The fact that the problem-solving skills of the nursing students who participated in our research proved to be at pretty good levels and that their social skill levels were also determined to be at good levels in the same way were, indeed, satisfactory results for our research. Durualp et al. (2009), who conducted a similar study on the nursing students in our country, determined that the problem-solving skill was an important precursor for social skill level. The results of this research seem to support the findings of our study.

\section{Conclusions and recommendations}

Considering the overall research, there was a correlation found between the problem-solving skills and social skill levels of the nursing students. As the problem-solving skills of the students increase, 
Ergün, G., \& Șimșek Arslan, B. (2017). Reviewing the relation between the problem solving skills of school of health students and their social skill levels. Journal of Human Sciences, 14(1), 902-913. doi:10.14687/jhs.v14i1.4384

their social skill levels increase along with it. The problem-solving and social skill levels of the students of the department of nursing care were found to be quite good. In the light of these results, the researchers recommend that the reasons as to why the problem-solving and social skill levels of the students who will be in charge of nursing career in the future are good to be investigated in more detail, and that the results be shared with the educational institutions training health professionals; in addition, it is also advised that the research be planned countrywide by no longer regarding it as a specific/authentic study, and that optional courses for developing social and problem-solving skills be included in the curriculums of the departments involved in health care, as well.

\section{References}

Altuntaş, S., \& Harmanc1, A. K. (2010). Nurse managers's conflict solving tendencies. HEAD, 7 (2), 5258.

Akın, S., Güngör, İ., Mendi, B., Şahin, N., Bizat, E., \& Durna, Z. (2007). Nursing student's problem solving skills and internal-external locus of control. HEAD, 4 (2), 30-36.

Akpinar, Ş. (2014). The investigation of the problem solving and social skills of teacher candidates. Kahramanmaraş/Turkey: Unpublished Master's Thesis.

Aşıt, T., Şendir, M., Acaroğlu, R., Öztürk, A., \& Büyükyllmaz, F. (2009). Evaluation of self-efficacy perception and problem solving efficiencies of first year students in college of nursing. Florence Nightingale Journal of Nursing, 17 (3), 151-157.

Avşar, Z. (2004). Determination of physical education and sport teachers' social skill levels. Uludağ University EFAD,17 (2), 111-130.

Avşar, Z., \& Kuter, F. Ö. (2007). Determination of social skills level in students of Uludağ University physical education and sports department. JTPE, 3(2), 197-206.

Bayındır, C..A., \& Olgun, N. (2014). Do problem-solving skills affect success in nursing process applications? an applicationamong Turkish nursing students. Int J Nurs Knowl, 26 (2), 90-95. View Article: DOI: doi: 10.1111/2047-3095.12043. Epub 2014 Aug 7.

Blanchard-Fields F. (2007). Everyday problem solving and emotion an adult developmental perspective. CDPS, 16 (1), 26-31. doi: 10.1111/j.1467-8721.2007.00469.x

Çağlayan, H. S., Tassğın, Ö., \& Yıldız, Ö. (2008). Analyzing skills of solving problems of high schools students who are doing sports from different angles considering variables. Niggde University Journal of Physical Education and Sport Sciences, 2 (1), 62-77.

Çam, S. (1999). The effect of communication skills training programme with teacher candidates, on ego states and perception of problem solving skill. TPCGJ, 2 (12), 16-27.

Çam, S., \& Tümkaya, S. (2008). Development of interpersonal problem solving inventory for high school students: The validity and reliability. JHS, 5 (2), 1-17.

Çinar, N., Sözeri, C., Şahin, S., Cevahir, R., \& Say, M. (2010). Problem solving skills of the nursing and midwifery students and influential factors. Rev Eletr Enf, 12 (4), 601-606. doi: 10.5216/ree.v12i4.8328.

Durualp, E., Arslan, D., Çayıroğlu, E., Özkan, S., \& Semerci, A. (2009). Analyzing the social skill effects on capability of problem solving skills of the students who are educating in school of health. In International Congress of Educational Research Congress Program and Abstracts Book, (p. 1-17). Çanakkale/Turkey.

Eskin, M. (2009). Basic concepts and definitions: problem-solving therapy. 3rd ed. Ankara: HYB Publishing.

Genç, S. Z., \& Kalafat, T. (2010). Prospective Teachers' Problem Solving Skills and Emphatic Skills. JTES, 3 (2), 135-147.

Güçlü, N. (1996). Education management and social skills. Educational Administration: Theory and Practice, 2 (4), 555-564.

Kanbay, Y., Aslan, Ö., Işık, E., \& Kilıç, N. (2013). Problem solving and critical thinking skills of undergraduate nursing students. J Higher Edu Sci, 3 (3), 244-251. Doi: 10.5961/jhes.2013.083 
Ergün, G., \& Șimșek Arslan, B. (2017). Reviewing the relation between the problem solving skills of school of health students and their social skill levels. Journal of Human Sciences, 14(1), 902-913. doi:10.14687/jhs.v14i1.4384

Kara, B. (2012). The investigation of paramedic candidates' problem solving skills and attitudes towards internet usage. TrJ Emerg Med, 12 (2), 54-61. doi: 10.5505/1304.7361.2012.42204

Karabulut, E.O., \& Pulur, A. (2011). A comparison of the problem solving skills of the representatives of juveniles from youth centers by different variables. Ankara University Faculty of Sport Sciences Spormetre, 9 (2), 71-80. doi: 10.1501/Sporm_0000000202

Kim, K. S., \& Choi, J. H. (2014). The relationship between problem solving ability, professional self concept, and critical thinking disposition of nursing students. International Journal of Bio-Science and Bio-Technology, 6 (5), 131-142. doi: 10.14257/ijbsbt.2014.6.5.13

Luthar, S. S. (1991). Vulnerability and resilience: A study of high-risk adolescents. Child Dev., 62 (3), 600616.Mueller, A., Johnston, M., Bligh, D., \& Wilkinson, J. (2002). Joining mind mapping and care planning to enhance student critical thinking and achieve holistic nursing care. International Journal of Nursing Terminologies and Classifications, 13(1), 24-27. doi: 10.1111/j.1744618X.2002.tb00161.x

Olgun, N. K., Öntürk, Z., Karabacak, Ü. E., Arslan, F., \& Serbest, Ş. (2010). Problem Solving Skills of The Nursing Students: Results of The 1-Year Observation Problem Solving Skills of The Students. ACU Health Sci J, 1(4), 188-194.

Özdemir, A. (2007). Examining the social skills of candidate educational administrators by some variables. Educational Administration: Theory and Practice, 50, 269-296.

Saracaloğlu, S., Serin, O., \& Bozkurt, N. (2001). The relationship between the problem solving skills and the achievement of graduate students of the graduate school of educational sciences. $M U$ Atatürk Education Faculty Journal of Educational Sciences, 14, 121-134.

Şahin, N., Şahin, N., \& Heppner, P. (1993). Psychometric properties of the problem solving inventory in a group of Turkish university students. Cogn Ther Res, 17 (4); 379-396.

Şahin, C. (2001). Social Skills and Social Competence. KEFAD, 2 (1); 9-19.

Şahiner, G., Açısö̈z, S., \& Açıkel, C. (2013). Student nurses' perceptions of their problem-solving ability. TAF Prev Med Bull, 12 (6), 673-680. doi: 10.5455/pmb.1-1354182988

Şenyuva, E., Kaya, H., \& Bodur, G. (2014). Effect social skills of nursing students of the project based teaching methods. Procedia-Social and Behavioral Sciences. 152, 393-398. doi:10.1016/j.sbspro.2014.09.218.

Taşç1, S. (2005). The Problem Solving Process in Nursing. ERU Journal of Health Sciences. 14 (Additional Issue: Special Issue of Nursing), 73-8.

Tezel, A., Arslan, S., Topal, M., Aydoğan, Ö., Koç, Ç., \& Şenlik, M. (2009). The investigation of the problem solving skill and depression level of nursing students. Journal of Anatolia Nursing and Health Sciences, 12 (4), 1-10.

Ünsar, S., Yıldız, F. Ü., Kurt, S. S., Erol, Ö., \& Ünsar, S. (2009). Emotional Intelligence Level of Edirne Health School Students. Science, Education and Thought Journal, 9(1), 13-27.

Yalçın, H. (2012). Research of social skills level for the teachers of preschool. Akademic Sight, 29; 1-11.

Yalçın, B., Tetik, S., \& Açıgöz, A. (2010). A study on the determination of the perceptions of problem solving skills and the levels of focus of control of high school students. Journal of Oryanization and Management Sciences, 2(2), 19-27.

Yang, S. (2010). Critical thinking disposition and problem solving ability in nursing students. J Korean Acad Nurs Admi, 16 (4), 389-398.

Yıldırım, A., Hacıhasanoğlu, H., Karakurt, P., \& Türkleş, P. (2011). Problem solving skills and influential factors in high school students. JHS, 8 (1), 905-921.

Yıldırım, A., Karakurt, P., \& Hacıhasanoğlu, R. (2009). Comparison of the problem solving skills with feeling and expression of anger in nursing students. Journal of Anatolia Nursing and Health Sciences, 12(1), 57-65.

Yoo, M. S., \& Park, J. H. (2014). Effect of case-based learning on the development of graduate nurses' problem-solving ability. Nurse Educ Today, 34 (1), 47-51. doi: 10.1016/j.nedt.2013.02.014. E pub 2013 Mar 19.

Yüksel, G. (1998). Adaptation of the Turkish social skills inventory: validity and reliability study. Psikolojik Danısma ve Rehberlik Dergisi, 2 (9), 39-48. 